\title{
NATOV KONCEPT STRATEŠKIH KOMUNIKACIJ V REPUBLIKI SLOVENIJI S POUDARKOM NA SLOVENSKI VOJSKI
}

\section{NATO'S STRATEGIC COMMUNICATIONS CONCEPT IN THE REPUBLIC OF SLOVENIA WITH EMPHASIS ON THE SLOVENIAN ARMED FORCES}

Povzetek Natov koncept strateških komunikacij, ki je osrednja tema prispevka, je v Sloveniji in Slovenski vojski premalo poznan in uporabljen pojem, še manj je znana njegova vsebina. Pogosto je napačno razumljen in enačen s strateškimi odnosi z javnostmi. Ni direktivno sprejet in uveden v procese odločanja in načrtovanja, vendar v ospredje vedno bolj prihaja zavedanje, da je nujen, in sicer z vsemi svojimi zmogljivostmi in na vseh ravneh delovanja, kot eden ključnih načinov celovitega pristopa $\mathrm{k}$ učinkovitemu reševanju kriz v svetu in vedno bolj tudi v domačem okolju.

Cilj pisanja je na diplomatski in vojaški ter taktični in strateški ravni spodbuditi zavedanje o nujnosti, pomembnosti in uporabnosti koncepta strateških komunikacij v sodobnem informacijskem času. S predstavitvijo teoretičnega okvira, vsebine in resničnih implikacij koncepta strateških komunikacij v praksi drugih držav, zavezniških in nasprotnikovih sil želimo s prispevkom poiskati zanimanje in pot do stvarne uvedbe in uporabe koncepta v slovenskem okolju. Analitični pregled stanja v Slovenski vojski in širše pokaže, da se sistem še ne zaveda nujnosti uvajanja koncepta v uporabo, čeprav bi se moral. V sklepu so zato zapisani izhodišča in podlaga za gradnjo obravnavanega koncepta $\mathrm{v}$ našem okolju, ki bodo predvsem v SV in na Ministrstvu za obrambo, pa tudi širše v slovenskem okolju, temelj za razpravo o oblikovanju nujnih odgovorov na izzive sodobnega varnostnega okolja.

Ključne Strateške komunikacije, strateško komuniciranje, StratCom, nekinetično besede delovanje.

Abstract In Slovenia and the Slovenian Armed Forces, NATO's Strategic Communication's Concept, which is the main topic of this article, is a little known and used term, while its contents is even less known. It is often misunderstood and compared to strategic public relations. It has not been regulated and incorporated into the decision-making and planning processes. However, the awareness of its paramount 
importance is coming more and more to the fore. It is needed with all its capabilities and at all levels of operation as one of the key ways of adopting a comprehensive approach to an effective resolution of crisis worldwide and, more and more, in Slovenia.

The aim of this article is to encourage the awareness on the urgency, importance and usefulness of the concept of strategic communication in the modern information era. By presenting the theoretical framework, contents and actual implications of the strategic communications concept in the practice of other nations, allied and adversary forces, we aim at ascertaining interest and way to actually implement and apply the concept in Slovenia. According to the analytical overview of the situation in the Slovenian Armed Forces and beyond, the system is not yet aware of the urgency of implementing the concept, although it should be. The conclusion thus includes the platform and foundation for the formulation of the discussed concept in Slovenian environment, which will serve as the basis for the Slovenian Armed Forces, the Ministry of Defence and other institutions to discuss the formulation of urgent responses to the challenges posed by the modern security environment.

\section{Key words Strategic communications, StratCom, non-kinetic operations.}

Uvod Desetletja se je Nato osredotočal večinoma na vojaško konvencionalno moč, medtem ko je imel informacijski del aktivnosti zavezništva dopolnilno in manj vidno vlogo (Bentzen, 2016). Danes, ko je svet postavljen pred nove izzive, ni več tako. Poleg vojaških hibridnih groženj se kot grožnje varnosti pojavljajo terorizem, uporniško delovanje, organizirani kriminal, ekstremizem, širjenje orožja za množično uničevanje, nezakonite migracije in trgovina $\mathrm{z}$ orožjem, zloraba informacijskih tehnologij, kibernetske grožnje, dejavnost tujih obveščevalnih služb ipd. Te težnje kažejo na vse več nekonvencionalnih varnostnih tveganj, ki zahtevajo učinkovit in usklajen odziv vojaških in civilnih struktur. Današnje in prihodnje varnostno okolje bo zahtevalo veliko prilagodljivost oboroženih sil, ki morajo biti sposobne odzivanja tako na klasične vojaške oblike ogrožanja kot tudi na nekonvencionalne oblike.

Leta 2007 je Vojaški odbor Nata (Military Commitee) opozoril Severnoatlantski svet (North Atlantic Council) na neučinkovitost operacije, javne diplomacije in vojaških odnosov z javnostmi v Afganistanu. Bili so tako neučinkoviti, da so že ogrožali doseganje zastavljenih ciljev zavezništva na območju delovanja (MCM0085-2010). Ob tem je odbor sprejel akcijski načrt za izboljšanje koncepta strateških komunikacij, s katerim sta se začela intenziven razvoj in uveljavljanje nekinetičnega delovanja, ki mora postati neločljivo povezan del vojaškega načrtovanja in izvajanja operacij. Po enem letu raziskav o dimenzijah, lastnostih, načelih, obsegu koncepta, naučenih lekcijah v Sierri Leone, Iraku in Afganistanu je bil leta 2010 podpisan Natov koncept za strateške komunikacije ${ }^{1}$. Tako je

Military Concept for Nato Strategic Communication, MCM-0085-2010 iz avgusta 2010, po tem, ko je bila v NAC septembra 2009 sprejeta Natova politika StratCom (MCM-0164-2009). 
obravnavani koncept postal eden štirih ključnih načinov Natovega celostnega pristopa k reševanju kriz v svetu ${ }^{2}$.

$\mathrm{V}$ iraški in afganistanski vojni sta se komuniciranje in upravljanje informacij dvignila na raven bojnih orodij in postala gibalo sprememb. Pri razpravah v zavezništvu o doseganju ciljev sil v Afganistanu so za opisovanje stanja pogosto uporabljali izraz »out-communicated by guys in caves « (v dobesednem prevodu: preglašeni od mož v jamah). Talibani so imeli že leta 2006 jasen načrt strateških komunikacij kot načina bojevanja, ki ga je zavezništvo začelo razvijati šele po tem spoznanju (Skelton, 2008).

Zgodili sta se nova ruska vojaška doktrina in ukrajinska kriza, soočamo se s fenomenom propadlih držav in zaostrovanjem varnostnih razmer na jugu. Videti je, da boj proti tem novim virom ogrožanja nacionalne in mednarodne varnosti ni mogoč le s sodobnimi tehničnimi sistemi, napadom in obrambo, temveč in predvsem tudi z uvajanjem novih konceptov nekinetičnega delovanja, ki postaja vedno pomembnejši tudi pri doseganju političnih in vojaških ciljev. $\mathrm{V}$ informacijski dobi, ko se globalnim grožnjam in krizam pridružijo globalna ekonomija, informacije 24 ur na dan, svetovno občinstvo, tehnološka revolucija, množica akterjev in dejstvo, da pridobitve sodobnega sveta pogosto nasprotnik bolj izkoristi kot mi, je še kako tehten premislek o uporabi koncepta strateških komunikacij (v angleškem izvirniku Strategic Communication in z uveljavljeno kratico StratCom) za doseganje političnih in vojaških ciljev zavezništva in nas samih.

Namen prispevka je predstaviti in opredeliti pojem in koncept strateških komunikacij, kot je opredeljen v severnoatlantskem zavezništvu, da bi ga lahko integrirano uvedli, razvili in uporabili v Slovenski vojski in na Ministrstvu za obrambo. Izhodiščna teza je, da Slovenska vojska še ni prepoznala pomembnosti in pomena koncepta strateških komunikacij in ga zato ni uvedla v vojaško odločanje in obrambno načrtovanje. Pa bi ga zagotovo morala čim prej glede na težo, ki jo konceptu pripisuje zavezništvo, znotraj katerega deluje, glede na institucionalno vpetost države v uvedbo Natovih konceptov ter glede na okolje, v katerem deluje.

Izbrana tematika zahteva uporabo različnih metod. V prvem delu prispevka temelji pisanje na celostni analizi pravnih aktov in dosegljive strokovne literature, njen cilj je obravnavanemu konceptu postaviti jasen teoretični okvir. Drugi del temelji na analitičnem premisleku, nastalem na podlagi kratkega intervjuja in pregleda sedanjih strateških dokumentov o stanju na tem področju v Slovenski vojski, na obrambno-varnostnem področju in širše v nacionalnem okolju. Uporabljena je metoda primerjave resničnega stanja z načrtovanim v Slovenski vojski, na Ministrstvu za obrambo in širše. Odgovore iščemo s pregledom dokumentov,

Znotraj obrambnega odzivanja na krize Nato deluje na štirih ključnih področjih: načrtovanje in izvajanje operacij; naučene lekcije, usposabljanje, izobraževanje in vaje; poudarjeno sodelovanje z zunanjimi akterji in strateško komuniciranje (ACO COPD, 2010). 
stvarnih primerov in aktivnosti Slovenske vojske, v katerih bi doktrinarno $\mathrm{v}$ zavezništvu morali uporabiti oziroma izvajati strateške komunikacije. V sklepu so na podlagi teorije, osebne izkušnje in opravljene analize navedene ključne končne ugotovitve.

Zato je tudi prispevek razdeljen na dva večja vsebinska sklopa. V prvem, ki je obsežnejši, so natančno opredeljeni pojem, koncept in razvoj koncepta strateških komunikacij, našteti so primeri uporabe pojma v nekaterih Natovih operacijah ter razložena je umeščenost tega procesa $v$ politično-vojaško načrtovanje. V drugem delu sta predstavljena Natov načrt uvajanja te zmogljivosti na nacionalne ravni ter stanje v Republiki Sloveniji, na Ministrstvu za obrambo in v Slovenski vojski. V sklepu sta zapisana pobuda za zagon koncepta strateških komunikacij v Republiki Sloveniji in njegovo vključitev v Slovensko vojsko oziroma na Ministrstvo za obrambo ter odgovor na raziskovalno vprašanje, ali se Slovenska vojska zaveda vsebine in zmogljivosti koncepta strateških komunikacij ter nujnosti njegove usklajene rabe na vseh ravneh obrambno-varnostnega sistema.

\section{O NATOVEM KONCEPTU STRATEŠKIH KOMUNIKACIJ}

Ključno za razumevanje koncepta je natančno poznavanje pomena in vsebine obravnavanega pojma in njegovih zmogljivosti, celostnega pristopa, ki ga omogoča, in povezanosti z različnimi deli (nad)nacionalnovarnostnega sistema. Predvsem zato, ker je koncept strateških komunikacij (v nadaljevanju StratCom) zavezništvo sprejelo že leta 2010, a še danes v slovenskem (vojaškem) okolju ni zaživel, ni vedno pravilno razumljen ali doktrinarno opredeljen, ni dovolj poznan niti uporabljen znotraj vseh svojih zmogljivosti. Tako ostaja neuporabljeno, a razpoložljivo orodje za doseganje skupnega želenega cilja institucije, države ali skupnosti.

\subsection{Opredelitev pojma}

Koncept strateških komunikacij je orodje in sredstvo vplivanja. Je obveščanje kot najbolj posredna oblika prisile in kot najbolj neposredna oblika oblikovanja mnenja v okolju. Največji učinek doseže, če so sporočila in javna podoba skladni z izrečenimi besedami in izvedenimi dejanji - ko ni say-do-gap ${ }^{3}$. Zavedati pa se je treba dejstva, da koncept ne more biti in ni »čudežno zdravilo« za slabe politike, napačno podprte in izvedene vojaške akcije ipd., kot tudi ni pavšalno enačenje s terminom odnosi z javnostmi.

Opredelitev koncepta je po večini enaka in v državah uporabnicah prilagojena nacionalnim značilnostim. Ključno vsem definicijam je zgodba (narrative), ki omogoča izvajanje vseh nalog, usmerjenih k enemu cilju, usklajeno in brez odstopanj.

3 Ko ni razlike med tem, kar govorimo in kar delamo oziroma obratno, naredimo tisto, kar rečemo. 
Ameriško ministrstvo za obrambo opredeli koncept strateških komunikacij kot prizadevanje razumeti in vključiti ključne javnosti in ciljne skupine v doseganje, ustvarjanje in izboljšanje ali ohranjanje razmer, ključnih za uveljavljanje in napredovanje državnih interesov, politik in ciljev ZDA. To je mogoče doseči s programi, sporočili in produkti, ki so usklajeni z uporabo drugih instrumentov nacionalne moči (GAO-12-612R Strategic Communication).

Na obrambni akademiji v Veliki Britaniji koncept strateških komunikacij opredelijo kot niz vztrajnih in usklajenih aktivnosti, ki se izvajajo na strateški, operativni in taktični ravni. Aktivnosti omogočajo razumevanje ciljnih skupin, prepoznavanje učinkovitih kanalov vplivanja ter razvijajo in spodbujajo zamisli in mnenja, ki zagotavljajo želen tip obnašanja, vedenja in odzivanja (Tatham, 2008, str. 4).

V Franciji koncept opredelijo kot proces, oblikovan za usklajevanje komuniciranja (besed in dejanj) med medvladnimi akterji in povečanja njegovega strateškega pomena. Njegov temeljni cilj je spreminjanje védenja in obnašanja ciljne populacije, ki sta pomembna za dosego skupnega cilja (Reeding, Weed, Ghez, 2010).

Nato uveljavi bolj aplikativno definicijo koncepta. Opredeli ga kot usklajeno in namensko uporabo Natovih informacijsko-komunikacijskih zmogljivosti in aktivnosti. To so dejavnosti javne diplomacije, odnosov z javnostmi, informacijskega delovanja (InfoOps) in psihološkega delovanja (PsyOps), ki so primerna podpora politiki, operacijam in delovanju zavezništva za doseganje ciljev Nata (MCM-0164-2009).

Iz Natove strateške definicije je Natovo Združeno poveljstvo za operacije (Allied Command Operations - ACO) razvilo svojo razlago koncepta: to je koncept, znotraj katerega se na primeren način uporabijo zmogljivosti javne diplomacije, odnosov z javnostmi in informacijskega ter psihološkega delovanja, ki so usklajene med seboj in z Natovim poveljstvom ter povezane z izvajanjem vojaških aktivnosti. Usklajene so tudi s političnimi usmeritvami in delujejo za čimprejšnje doseganje ciljev zavezništva (ACO AD 95-2).

Za boljše razumevanje zmogljivosti koncepta in za zavedanje širokih možnosti njegove uporabe ni odveč poznavanje definicij njegovih posameznih elementov.

Za opredelitev termina javna diplomacija $\mathrm{v}$ obravnavanem pomenu kot sestavnega dela koncepta je treba najosnovnejšo, tradicionalno definicijo razširiti ${ }^{4}$. Tradicionalno gledano je usmerjena $\mathrm{v}$ mednarodne odnose. Z napredkom in sodobnimi izzivi postane javna diplomacija sredstvo za uporabo novih strategij, drugačnih načinov komuniciranja in prisotnosti modernih komunikacijskih kanalov ter orodij, ki neizogibno in nujno osredotoča aktivnosti diplomacije

\footnotetext{
Tuch (1990, 3) zapiše tradicionalno opredelitev javne diplomacije; predstavlja vladne procese komuniciranja in vzpostavljanja odnosov z javnostmi v tujini, katerih namen je doseči razumevanje nacionalnih zamisli in idealov, institucij in kulturo ter druge nacionalne, varnostne in obrambne cilje ter politike.
} 


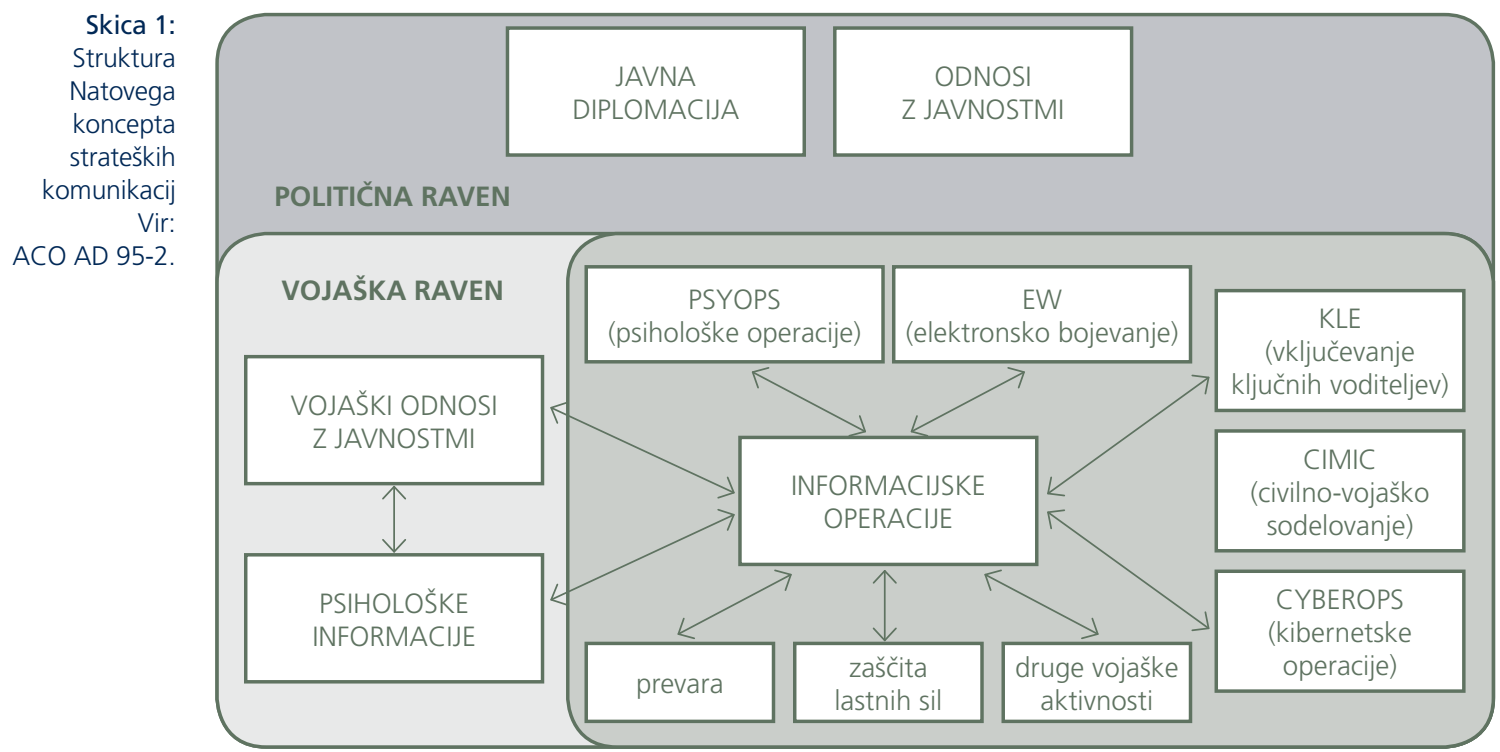

tudi na delovanje v domačem okolju. Po Natu je glavni cilj javne diplomacije obveščanje širše javnosti o zavezniških aktivnostih in politiki. To se izvaja prek različnih medijev (novinarske konference, izjave za javnosti, spletne strani, Natova $\mathrm{TV}$ ), s seminarji, predavanji in okroglimi mizami (http://brussels.mission.si/index. php?id=3020) $)^{5}$.

Nato informacijsko delovanje ${ }^{6}$ spoznava kot vojaško funkcijo, prek katere se zagotavljata svetovanje in usklajevanje vojaških informacijskih dejavnosti, s čimer se želijo doseči želeni učinki na voljo, razumevanje in zmogljivosti nasprotnikov, morebitnih nasprotnikov ter drugih skupin (odobrenih v NAC) (MC 422/3).

\footnotetext{
V tem kontekstu pojem razume tudi Melissen (2005, str. 22), ki govori o sodobni javni diplomaciji. Koncept javne diplomacije pojmuje širše kot prenašanje sporočil, vzpostavljanje diplomatskih odnosov, kampanje s predstavniki tujih ciljnih skupin in javnosti. Sodobna javna diplomacija poleg doseganja zunanjepolitičnih ciljev obsega tudi gradnjo odnosov s ciljnimi skupinami v civilnih družbah v tujini in predvsem pospeševanje sodelovanja med javnostmi doma.

${ }^{6}$ Furlan (2008) v Vojaški doktrini opredeli InfoOps kot: »način bojnega in nebojnega delovanja, ki se izvaja $v$ miru in vojni v podporo političnim ali vojaškim ciljem, z namenom vplivanja na osebe, ki sprejemajo odločitve. Deluje se na njihove informacije, procese obdelave informacij, sisteme poveljevanja in kontrole ter komunikacijske in informacijske sisteme, pri čemer se ščitijo lastne informacije in komunikacijski ter informacijski sistem. Informacijsko delovanje vključuje celotni spekter defenzivnih in ofenzivnih aktivnosti, ki se uresničujejo z načrtovanjem in izvajanjem ukrepov varnosti delovanja, z zavajanjem, psihološkim delovanjem, elektronskim bojevanjem, informiranjem javnosti, fizičnim uničenjem elementov sistemov poveljevanja in kontrole ter drugimi ukrepi ob istočasni obrambi lastnih sistemov poveljevanja in kontrole."
} 
Po Furlanu (2008)7 in tudi po AJP 3.10 (2009) je psihološko delovanje navedeno kot del informacijskega delovanja, v konceptu pa je iz njega izločeno in vstavljeno v strukturo strateških komunikacij kot samostojen element. Njegova opredelitev ostaja enaka. AJP 3.10 (2009) ga opredeli kot orodje vplivanja na zaznave, odnose in vedenje izbranih posameznikov ter skupin, skladno $\mathrm{z}$ odobrenimi ciljnimi populacijami Severnoatlantskega sveta. Cilj psihološkega delovanja je uveljaviti sprejetje zavezniških ciljev skladno s strateškimi usmeritvami o izvajanju informacijskih in operativnih nalog.

Zaradi tesne povezanosti koncepta $\mathrm{z}$ drugimi informacijskimi delovanji med njimi pogosto ni mogoče najti jasne meje in lahko pride do zamenjave pojmov. Ker gre $\mathrm{v}$ našem prostoru za razmeroma nov in nepoznan termin, je za lažjo predstavo pomembno vedeti, kaj koncept strateških komunikacij ni in kaj je. To niso le odnosi z javnostmi ali javna diplomacija, ni samo medijska akcija ali zelo pomembna tiskovna konferenca. Koncept strateških komunikacij se ne uporablja kot drugo ime za informacijsko delovanje in ne za opisovanje političnega posveta generalnega sekretarja. To niso le močna sporočila, ponavljajoča se besedila, udarni naslovi, vsiljevanje informacij. Koncept je strateško razmišljanje, ki je pravočasno, stalno, načrtovano in usklajeno z drugimi dejavniki na območju izvajanja. Je projekt, temelječ na dopolnjevanju in združevanju naporov, v katerem je del načrtovane informacijsko-komunikacijske aktivnosti, s katerimi skupaj dosežejo strateški učinek (Tatham, 2008, str. 8, in Galoforo, 2012).

Sklenemo lahko, da je koncept strateških komunikacij mehanizem vpliva. Spekter vplivanja sega od obvestiti kot najbolj posredne oblike do prisiliti kot najbolj neposredne oblike vpliva. Vse ravni Natovega delovanja imajo pomembno informacijsko-komunikacijsko komponento, ki ni podporna, ampak neločljiva in enakovredna dejavnost vojaških aktivnosti.

\subsection{Terminološka zmeda in prepoznavanje koncepta med zaveznicami}

Izvirna besedna zveza Strategic Communication ni idealna in povzroča pojmovno zmedo. Bila je sprejeta in se je obdržala v zavezništvu zaradi dveh vzrokov. Prvi je, da je pojem Strategic Communication edini sprejemljiv za vse članice zavezništva, drugi pa, da se je že pred oblikovanjem Natovega koncepta v ZDA razvil vsebinsko enak koncept, $\mathrm{z}$ enakim imenom. V literaturi se pojavlja veliko terminov, ki bi lahko imeli podobno vsebino in namen, a imajo prav tako kakor StratCom svoje omejitve in so zaradi konotacije za nekatere zaveznice popolnoma nesprejemljivi. Ti izrazi so: vplivanje, strateško vključevanje javnosti, globalno vključevanje, strateški učinki, informiranje, vplivanje in prepričevanje (Reeding, Weed, Ghez, 2010).

\footnotetext{
»Psihološko delovanje je načrtovana psihološka dejavnost v miru in vojni, usmerjena v sovražne, lastne ali nevtralne ciljne skupine z namenom vplivanja na njihovo stališč in vedenje v podporo doseganju političnih ali vojaških ciljev. Cilj psihološkega delovanja je slabiti sovražnikovo voljo do bojevanja, izboljšati podporo in lojalnost lastnih in prijateljskih ciljnih skupin ter pridobiti podporo neodločenih ali nevtralnih. Obsega strateške psihološke aktivnosti, psihološko konsolidacijo in psihološke aktivnosti na bojišču. (Furlan, 2008)
} 
Še dodatno pojmovno zmedo vnaša prevajanje Strategic Communication v slovenski jezik. Mogoča sta dva prevoda: strateške komunikacije in strateško komuniciranje. Prvi prevod je primernejši glede na vsebino koncepta in zmogljivosti, ki jih vsebuje, drugi je v proučevanem okolju bolj uporabljen in pogostejši, a največkrat razumljen preveč preprosto. Komuniciranje je v slovenskem prostoru (in tudi $\operatorname{drugod}^{8}$ ) večinoma napačno razumljeno in enačeno s pojmoma odnosi z javnostmi in medijske aktivnosti.

V prispevku je uporabljen prevod strateške komunikacije, da je zadoščeno vsebinski komponenti in da je omogočeno lažje ločevanje od ponekod že uveljavljenih služb za strateško komuniciranje (kot npr. v nadaljevanju omenjena Služba za strateško komuniciranje Ministrstva za obrambo), ki ne vsebujejo vseh zmogljivosti koncepta.

Poleg napačnega razumevanja besede komuniciranje je težava tudi $\mathrm{v}$ besedi strateško, ki po vsebini postavlja delovanje in učinke koncepta na strateško, to je najvišjo raven odločanja in delovanja, čeprav po svoji vsebini in učinkih pokriva vse od strateške do operativne in taktične ravni.

Poleg terminološke zmede se pojavlja tudi različna stopnja prepoznave pomembnosti in sprejetja koncepta med članicami. Center odličnosti za StratCom v Rigi je v prvi polovici leta 2015 v Natu opravil anketo o poznavanju koncepta. Opravljenih je bilo 11 anket in šest strukturiranih intervjujev. Ugotovitve so pokazale, da večina (6/11) anketiranih držav v svojo zakonodajo sprejema Natovo opredelitev strateških komunikacij, a jo le ena četrtina vprašanih uresničuje na doktrinarno predpisan način $\mathrm{z}$ osredotočenjem na zgodbo in $\mathrm{z}$ oblikovanjem strategije, temelječe na komuniciranju (z usklajevanjem besede, slike in dejanj). Še večje razhajanje med konceptom in resničnim stanjem pokažejo strukturirani intervjuji. Le redko članice sprejmejo strateške komunikacije kot vodstveno (poveljniško) orodje, kot »mindset«, ki lahko vpliva in spreminja tako odnose kot prepričanja in obnašanje ciljnih populacij. Prav tako se članice razlikujejo v razumevanju ravni vplivanja učinkov koncepta. Večinoma velja prepričanje o doseganju strateških učinkov, kar pa ni skladno z vsebino koncepta, ki umešča koncept na vse ravni delovanja. Omeniti velja še skoraj enotno dojemanje članic $(10 / 11)$, da gre za medvladno in medresorsko sodelovanje, da je StratCom treba razviti kot poveljniško funkcijo, da je sestavni del vsakega političnega ali vojaškega načrtovanja in da bo njegova uvedba v prakso povzročila nekatere organizacijske spremembe (Mapping of StratCom, 2015). Zato je pomembno zavedanje, da StratCom ni le orodje vojaških organizacij, temveč je namenjen predvsem delovanju na vseh ravneh $\mathrm{v}$ različnih civilnih in vojaških okoljih, $\mathrm{z}$ enim poslanstvom - zgodbo države, zavezništva, operacije in politike enotno ter usklajeno pripeljati do želenega cilja.

\footnotetext{
Npr. Francija se sooča s podobnim izzivom. V raziskavi Reeding, Weed, Ghez (2010), o primernosti Natovega StratCom za uvajanje v francosko okolje so jasno opozorili, da bi uvedba koncepta, kot je doktrinarno opredeljen v zavezništvu, vnesla veliko pojmovne zmede.
} 


\subsection{Civilni pomen Natove politike strateških komunikacij}

Za pomoč pri razumevanju razsežnosti koncepta strateških komunikacij tudi $\mathrm{v}$ civilnem političnem okolju lahko služi njegova primerjava z orkestrom. V vlogi dirigenta se $\mathrm{v}$ državah znajdejo vlade, na ravni zavezništva (NAC). Glasbena ekipa, sestavljena iz resornih ministrstev, parafrazira načrt StratCom. Posamezna orkestralna zasedba predstavlja različno dejavnost državnega subjekta in posamezno fazo operacije oziroma delovanja. Glasba sama je zgodba organizacije, države, poslanstvo neke operacije. Glede na želeni cilj se načrtujejo čas, vložki in tempo posamezne zasedbe. Dirigent pa je tisti ključni člen, ki zagotavlja, da vsi igrajo glasbo enakega notnega zapisa (Tatham, 2008, str. 4-8).

Kako pomembno je izvajanje koncepta na vseh ravneh in v vseh okoljih (civilnopolitičnem in obrambno-vojaškem), je razvidno tudi iz Natove opredelitve, ki pri določanju koncepta posebej izpostavi, da gre za medresorski in medvladni projekt. V praksi se koncept naslanja na vojaške zmogljivosti s področij informacijskega in psihološkega delovanja ter vojaških odnosov z javnostmi, ki jih komplementarno dopolnjujejo civilne aktivnosti javne diplomacije, in odnosov z javnostmi. Lažjo predstavo področij delovanja posameznih zmogljivosti ponuja preglednica 1, iz katere sta razvidni tudi tesna prepletenost $\mathrm{v}$ delovanju in zato potreba po zares usklajenem (tudi medresorsko) delovanju za doseganje optimalnega učinka.

\begin{tabular}{|c|c|c|c|c|c|}
\hline \multirow{4}{*}{$\begin{array}{r}\text { Preglednica 1: } \\
\text { Razmejitev } \\
\text { pristojnosti med } \\
\text { posameznimi } \\
\text { elementi } \\
\text { StratCom }\end{array}$} & & $\begin{array}{l}\text { Informacijsko } \\
\text { delovanje }\end{array}$ & $\begin{array}{l}\text { Psihološko } \\
\text { delovanje }\end{array}$ & Odnosi z javnostmi & Javna diplomacija \\
\hline & Namen & $\begin{array}{l}\text { vplivanje na voljo, } \\
\text { razumevanje in } \\
\text { sposobnosti }\end{array}$ & $\begin{array}{l}\text { vplivanje na zaznave, } \\
\text { obnašanje in odnose }\end{array}$ & $\begin{array}{l}\text { obveščanje in } \\
\text { vzpostavitev } \\
\text { kredibilnosti }\end{array}$ & $\begin{array}{l}\text { vplivanje s političnim } \\
\text { delovanjem }\end{array}$ \\
\hline & Javnosti & $\begin{array}{l}\text { (mogoči) nasprotnik, } \\
\text { druge NAC, } \\
\text { odobrene }\end{array}$ & $\begin{array}{l}\text { NAC, odobrene } \\
\text { znotraj AOR }\end{array}$ & $\begin{array}{l}\text { zavezniki, } \\
\text { mednarodna, lokalna } \\
\text { skupnost }\end{array}$ & $\begin{array}{l}\text { politične skupine, } \\
\text { mediji, organizacije }\end{array}$ \\
\hline & Področje & $\begin{array}{l}\text { kinetično in } \\
\text { nekinetično } \\
\text { delovanje }\end{array}$ & $\begin{array}{l}\text { Natovi mediji in } \\
\text { druga sredstva } \\
\text { komuniciranja }\end{array}$ & $\begin{array}{l}\text { nekinetično medijsko } \\
\text { delovanje }\end{array}$ & $\begin{array}{l}\text { nekinetično politično } \\
\text { delovanje }\end{array}$ \\
\hline
\end{tabular}

$\mathrm{Na}$ Ministrstvu za zunanje zadeve RS se zavedajo pomena strateškega komuniciranja ${ }^{9}$, predvsem takrat, ko se naslanja na javno diplomacijo in odnose $\mathrm{z}$ javnostmi, a ga ne povezujejo naprej z drugimi elementi koncepta. V strateškem

\footnotetext{
V dokumentu (Slovenija, 2015) uporabijo koncept strateško komuniciranje, kar dodatno potrjuje pravilnost odločitve o uporabi prevoda strateške komunikacije, ki vsebinsko in konceptualno lahko predstavlja nadgradnjo že uveljavljenega termina strateško komuniciranje.
} 
dokumentu zunanje politike RS je zapisano, da so strateško komuniciranje ter javna in kulturna diplomacija pomembni elementi mehke moči slovenske zunanje politike. Prepoznavnost RS kot varne, odprte, odgovorne, kulturno bogate in uspešne države je ključna za utrditev njenega gospodarskega položaja. Poudarijo, da javna diplomacija tesno sodeluje z drugimi vladnimi resorji in agencijami (Slovenija, 2015, str. 31). Poleg tega so v dokumentu zapisana tudi ključna sporočila RS ter zgodba $^{10}$ in blagovna znamka I feel Slovenia (Slovenija, 2015, str. 3-4).

StratCom je postal tudi ključni del Natovega celovitega pristopa pri reševanju kriz.

Za razumevanje celotnega koncepta je dovolj zavedanje, da je StratCom orodje civilne politične veje oblasti in drugih organizacij. Ker je pozornost članka usmerjena $\mathrm{v}$ proučevanje obrambno-vojaškega vidika StratCom, bo zato $\mathrm{v}$ nadaljevanju natančneje razčlenjen in obdelan le njegov vojaški vidik.

\subsection{Vojaški vidiki Natove politike strateških komunikacij}

Vsako dejanje, beseda in slika pošljejo sporočilo in poštar je vsak izmed nas. Vsaka operacija, tudi najmanjše taktično delovanje, ima lahko strateške posledice. Zato je StratCom kljub strateško zvenečemu imenu še kako taktično uporaben.

Namen Natovega koncepta strateških komunikacij je zagotoviti, da bodo vse ciljne, prijateljske ali nasprotnikove javnosti in skupine $\mathrm{v}$ državi ali regiji delovanja dobivale resnične, točne in pravočasne informacije, ki jim bodo omogočale razumeti in oceniti dejanja ter namere zavezništva, kar naj bi odvračalo agresijo in spodbujalo sprejetje Natovih namer in ciljev (MCM-0085-2010).

\section{Vojaške implikacije StratCom (povzete po Military Concept for NATO StratCom):}

- Razmejitev odgovornosti

Natov StratCom je proces vodenja, usmerjen in osredotočen na povečanje sposobnosti zavezništva za usklajeno artikulacijo svoje zgodbe ${ }^{11}$, teme in sporočila, do zunanje in notranje javnosti ter različnih ciljnih skupin. Izvaja se z uporabo že omenjenih informacijsko-komunikacijskih zmogljivosti, ki so med seboj usklajene in povezane.

Najpomembnejše pa je zavedanje, da sta uvedba in izvajanje StratCom poveljniška odgovornost, ki bi morala biti del koncepta poveljevanja s poslanstvom.

\footnotetext{
${ }^{10}$ Zgodba zunanje podobe Slovenije z motom: »V svetu uveljavljati varnost, blaginjo in ugled Republike Slovenije in njenih ljudi.« (Slovenija, 2015, str. 1)

${ }^{1 I}$ Zavezništvo za vsako svojo aktivnost oblikuje posebno zgodbo, ki ji sledijo in jo uresničujejo vse druge aktivnosti. Najbolj splošna zgodba zavezništva sporoča: Nato je organizacija, ključnega pomena za ohranjanje in uveljavljanje varnosti in miru svojih članic, kar dosega s političnimi in vojaškimi sredstvi (http://www.nato. int/nato-welcome/index.html). Ob krizi v Ukrajini je Nato zavzel zgodbo »nevmešavanja«ipd.
} 
- Vojaške operacije

Izvajanje vojaških operacij prinaša v komunikacijske enačbe uporabo sile (kar ločuje vojaški in politični StratCom). Na politični ravni komunikacija poteka večinoma z uporabo besed. Sporočilo, ki ga oddajajo pogosto tudi smrtonosne vojaške operacije, pa zahteva ustreznejše, bolj premišljeno in usklajeno izvajanje komunikacijskih in informacijskih dejavnosti Nata. V vojaških operacijah dejanja govorijo vsaj tako glasno kot besede, če ne glasneje, zato je vključevanje strateške komunikacije od začetka do konca v vojaški proces odločanja več kot nujno $^{12}$.

- Posledice in rezultati

Vse, kar zavezništvo ali članice rečejo, naredijo ali ne, tudi če česa ne rečejo, ima (želene ali neželene) posledice. StratCom se izvaja na vseh ravneh vodenja in poveljevanja, od strateške do taktične. Vsako dejanje, beseda in slika pošljejo sporočilo v okolje, in vsak vojaški član je poslanec, od posameznega vojaka do poveljnika operacije. Tudi najmanjše dejanje ima lahko strateške posledice ${ }^{13}$. Vojaški prispevek zato zahteva skrbni ter stalni analizo in oceno, ki pošiljata povratne informacije (feedback) v proces operativnega načrtovanja in ukrepanja, da je mogoče prilagoditi sredstva in cilje na vseh ravneh delovanja.

- Vodenje in poveljevanje

Strateške komunikacije so v poveljniški pristojnosti in odgovornosti. Poveljevanje s poslanstvom mora biti na tem področju še posebno jasno - jasni morajo biti namera in prednosti, cilji in namen.

- Organizacija

Izvajanje StratCom lahko povzroči spremembe v vojaških organizacijah, saj zahteva omrežno-centralistični pristop in hitrost odločanja, ki sta lahko v nasprotju z bolj tradicionalnimi, hierarhičnimi vojaškimi strukturami. StratCom zahteva nenehen, sodelovalni pristop, ki mora biti vertikalno (od strateške do taktične ravni) in horizontalno (med vsa funkcijska področja) vpet proces. Voditelji pa imajo nalogo sinhronizirati zmogljivosti in instrumente moči za doseganje želenih učinkov.

- Pooblastila za širjenje zgodbe

Pri tem je treba preseči tradicionalno omejenost komuniciranja na najvišji ravni s prenosom pooblastil za komuniciranje in informacijsko delovanje na nižje ravni delovanja (operativni in taktični). Prenos mora biti pripravljen vnaprej in natančno opredeljen, kar zahteva učinkovito pripravo, usposabljanje, zavedanje o pomenu in vsebini informacij ter visoko varnostno kulturo. Le vse to lahko

\footnotetext{
12 V Natov proces kriznega upravljanja (Comprehensive operations planning).

${ }_{13}$ Pri pregledu literature je mogoče zaslediti več taktičnih ravnanj, ki so imela neslutene strateške posledicenpr: uriniranje oddelka ameriških marincev na Koran, podiranje Sadamovega kipa v Libiji, fotografije iz Abu Graipha ipd. (kot je razvidno tudi iz kolaža slik št. 3).
} 
zagotovi pravočasno in verodostojno komuniciranje ter prepreči razhajanje med besedami in dejanji na taktični ravni ${ }^{14}$.

- Urjenje strokovnjakov

Ne nazadnje je uspeh Natovega koncepta strateških komunikacij odvisen od pripravljenosti in sposobnosti držav članic pri zagotavljanju izkušenega in strokovno usposobljenega osebja ter v nacionalnih okvirih uveljavljenega in razčlenjenega Natovega koncepta strateških komunikacij.

Za uspešno izvajanje strateškega komuniciranja je skladno s konceptom in znotraj vojaških zmogljivosti treba zagotoviti devet ključnih elementov:

- usklajevanje Natovih in koalicijskih sil, informacij, sporočil in komunikacijskih aktivnosti (integracija StratCom v proces načrtovanja, izgradnja enotnega zavedanja situacije);

- vključitev StratCom v širšo Natovo strategijo odzivanja v kriznem okolju na način celostnega pristopa (identifikacija zunanjih virov vplivanja, vzpostavitev močnih povezav s civilnim okoljem, usklajevanje elementov zunaj zavezništva, spremljanje in ocenjevanje učinkov);

- zmožnost posredovanja in vzdrževanja pravočasnih informacij, sporočil in znanja do prepoznanih ciljnih skupin ter vplivanje nanje (identifikacija ciljnih skupin, ustvarjanje relevantne podatkovne baze, izbira kanala komuniciranja ipd.);

- vplivanje na različne medije in vzpostavitev celovite socialne komunikacije;

- zagotovitev prenosa in končna izvedba načrta StatCom v okolju delovanja;

- ocena in iskanje povratnih informacij ob aktivnostih StratCom (vpliv na javnost, analiza medijev, zavedanje situacije, kdo je kdo, ankete ipd.);

- zagotovitev razmer za razvoj in širjenje pravočasno in kulturno sprejemljivih sporočil, ki izhajajo iz skupne Natove zgodbe (opredelitev ciljnih skupin za določena sporočila, identifikacija primernih medijev za svojo promocijo oziroma propagando v okolju delovanja, izbira ustreznega časa poročanja, pogostost, vsebina in oblika ipd.);

- zagotovitev hitrega razvoja in širjenja informacij za vplivanje na izbrano populacijo;

- širjenje informacij za vplivanje na potek situacije in njihovo posredovanje $\mathrm{v}$ realnem ali skoraj realnem času (MCM-0085-2010).

Ključno pri izvajanju koncepta je, da se v proces kriznega odločanja že na začetku načrtovalnega procesa vključijo posamezni strokovnjaki s področja StratCom in so vanj vključeni ves čas načrtovanja, do konca zadnje faze. Vojaški načrtovalci bi morali težiti k temu, da se StratCom integrira v operativno načrtovanje od najzgodnejših faz. A največji izziv je miselnost vojaških načrtovalcev in pogosto tudi voditeljev, da se nekinetični in spoznavni procesi v načrtovalni proces med vso fazo načrtovanja in izvedb vključujejo enakovredno kot drugi vojaški (bojni) procesi.

\footnotetext{
${ }^{14}$ Nujnost prenosa pooblastil in priprava taktične ravni StratCom sta jasno razvidni na primeru ameriških marincev, ki so na misiji v Afganistanu urinirali po truplu talibana (več o tem na: https://www.theguardian.com/ world/2012/sep/24/us-marines-charged-dead-taliban). Taktično dejanje posameznika na terenu s strateškimi implikacijami in izjemnim vplivom na potek operacije.
} 
Kot izhodišče za nadaljnje pisanje in v razmislek SV o nujnosti uvedbe koncepta $\mathrm{v}$ uporabo se poraja vprašanje, zaradi katerega se bo predstavljeni koncept razvijal in nadgrajeval tudi v prihodnje in postajal vse pomembnejši, in sicer: ali je mogoče zmagati $\mathrm{z}$ besedami ${ }^{15}$.

\subsection{Izzivi na poti do sprejetja koncepta strateških komunikacij}

Kako se spopasti z izzivi uvajanja novega koncepta? Kaj naredi strateško komuniciranje zares strateško? Kako uvesti koncept v operativno uporabo? Kako doseči učinkovitost strateških komunikacij na vseh ravneh delovanja? Kaj dovoliti v miru in kaj v krizi ...

Vprašanj je mnogo, dvomov in izzivov še več, a z upoštevanjem preprostega pristopa h konceptu, označenega kot $5 \mathrm{~S}^{16}$, in načel StratCom (zapisanih v nadaljevanju), ki izhajajo iz NATO Strategic Communications Policy (DSG(2010)0528), lahko StratCom znotraj procesa Natovega kriznega odzivanja iz izziva preide v izredno uporabno orodje za doseganje končnih ciljev zavezništva. Načela StratCom so:

- vzpostavitev StratCom kot specialističnega védenja, saj znotraj koncepta ni več prostora za improvizacijo, treba je oblikovati karierno pot za specialiste, nameniti proračunska sredstva za njegov nadaljnji razvoj ipd.;

- integracija profesionalcev za strateške komunikacije, ki morajo postati sestavni del vseh procesov odločanja in preigravanja, integrirani morajo biti vertikalno in horizontalno ter sprejeti v odnos aktivnega sodelovanja;

- sinhronizacija (racionalizacija) vseh vrst strateških komunikacij je najzahtevnejša naloga (zagotoviti ločenost, a hkrati povezanost informacijskih in psiholoških operacij, nepodvajanje dela in vzporednih, nepovezanih struktur). S sinhronizacijo se povečuje verodostojnost ter izmenjujejo organizacijski cilji na vseh ravneh, na ravni strateške politike in taktičnih vojaških aktivnosti;

- uvesti je treba dolgoročen proces, kratkoročne aktivnosti so nesprejemljive, ker so neučinkovite. Rezultati in spremembe v ciljnih skupinah se ocenjujejo dolgoročno, treba je poskusiti, si upati in tvegati;

- načrtovanje strateških komunikacij je nepogrešljivo. Nujni so učinkovito usklajevanje, sinhronizacija skupnih ciljev, aktivnosti in sporočil, harmonija vseh udeležencev, določanje ciljnih skupin, časovnice in sredstev ter mehanizma vrednotenja;

- iz sedanjih struktur in mehanizmov je treba zgraditi zmogljivost StratCom in procese, določiti naloge in pristojnosti ter se zavedati omejitev koncepta;

- pot naprej je mogoča le ob zavedanju dejstev, da je StratCom ena ključnih vojaških funkcij. Da je koncept, ki bo zaradi spremenljivega varnostnega okolja vedno v gradnji. Strateške komunikacije morajo postati modul temeljnega usposabljanja vsakega vojaka.

\footnotetext{
15 Vizvirniku »winning with words" (Haddock, 2002).

${ }^{16} 5$ S-pristop v izvirniku pomeni: Simplify (poenostaviti), Shorten (skrajšati), Share (deliti), Sustain (vzdrževati) and Staff ((kadrovsko) popolniti).
} 
Treba se je zavedati možnosti zlorab koncepta in težav tradicionalnega gledanja na (ločeno) delovanje vojaških organizacij v miru in vojni, v kriznem in domačem okolju. Vendar je koncept uporaben v vsakem času in okolju (podobno kot sistem kriznega upravljanja), vendar ob upoštevanju tega, da so učinki in cilji različni. Lahko trdimo, da so organizacija, proces in večina metod dela ${ }^{17}$ enaki v domicilnem okolju in $\mathrm{v}$ operaciji. $\mathrm{V}$ operaciji na primer propaganda vpliva na izbrano populacijo, da bi ta sprejela zavezniške sile in bi se vzpostavilo mirno in stabilno okolje za državljane. V domačem okolju pa se takšno okolje gradi z obveščanjem in promocijo, s sprejemljivostjo in prepoznavnostjo vojaške organizacije za okolje, $\mathrm{v}$ katerem deluje, z izboljšanjem civilno-vojaških odnosov, usklajenim pojavljanjem vseh akterjev v okolju, kar posredno zagotavlja človeške vire in splošno podporo.

Upoštevajoč prizadevanja ob uvajanju in razvoju Natovega koncepta strateškega komuniciranja je videti, da je mogoče nekatere vojaškopolitične cilje doseči tudi z informacijsko vojno in da strateške komunikacije z vsakim dnem postajajo pomembnejše. Temu pritrjuje tudi v nadaljevanju predstavljena uporaba strateških komunikacij v posameznih aktualnih krizah.

\subsection{Strateške komunikacije v resničnih krizah sodobnega sveta}

Znotraj zastavljene tematike ni prostora za natančne študije primerov uporabe strateških komunikacij v posameznih krizah (kot npr. v knjigi Analysis of Russia's Information Campaign against Ukraine, 2015), ampak je namen poglavja le splošna predstavitev najbolj značilnih in ključnih primerov uporabe strateških komunikacij v realnih kriznih situacijah. S tem želimo predstaviti težo StratComa in realnost njegove ključne vloge pri doseganju ciljev zavezništva in tudi nasprotne strani.

Nato se je s strateškimi komunikacijami v takšni obliki, kot so pozneje predstavljene v njegovem konceptu, prvič srečal v Afganistanu, ko so (kot že omenjeno) ob analizi o doseganju ciljev sil Isafa ugotovili, da so bili »out-communicated by guys in caves«. Natančna analiza je pokazala, da so med letoma 2006 in 2008 Talibani razvili izredno učinkovit in dobro organiziran informacijsko-komunikacijski načrt, ki je bil poleg terorističnih napadov ključni element njihovega koncepta strateških komunikacij.

Kriza v Libiji in operacija Enotna zaščita (Operation Unified Protector - OUP) sta bili prvi test novemu Natovemu konceptu StratCom. Preizkušeni so bili načrt, mehanizmi in primernost strateških komunikacij, s čimer so $\mathrm{v}$ zavezništvu na podlagi naučenih izkušenj dopolnjevali koncept. Veliko o uporabi novega koncepta pove preglednica 2, ki tabelarično prikazuje in primerja način delovanja strateških komunikacij pred razvojem koncepta strateških komunikacij in po njem.

\footnotetext{
${ }^{17}$ Razen metod psihološkega delovanja, neposrednega vplivanja, propagande in bojnega delovanja.
} 


\begin{tabular}{|c|c|c|}
\hline \multirow{6}{*}{$\begin{array}{r}\text { Preglednica 2: } \\
\text { StratCom v } \\
\text { Isafu in Enotni } \\
\text { zaščiti - } \\
\text { primerjava } \\
\text { Vir: } \\
\text { http://wwvv. } \\
\text { nato.int/cpsien/ } \\
\text { natolive/71679. } \\
\text { htm. }\end{array}$} & Isaf, Afganistan & Enotna zaščita, Libija \\
\hline & StratCom kot orodje za »popravljanje«. & StratCom kot pravočasen svež pristop. \\
\hline & StratCom upravlja delujoče mehanizme. & Pomanjkanje strateških usmeritev za StatCom. \\
\hline & V ospredju so aktivnosti PR. & $\begin{array}{l}\text { PR je samostojna dejavnost, usklajena } \\
\text { z drugimi elementi StratCom, ni v ospredju. }\end{array}$ \\
\hline & Dolga doba reševanja kriz. & Hiter razvoj odziva in reševanja kriz. \\
\hline & Fizična prisotnost na ozemlju delovanja. & Ni prisotnosti na območju delovanja. \\
\hline & Vse zaveznice so vpletene. & Ne prispevajo vse, skladno z dogovorom. \\
\hline
\end{tabular}

Med najbolj znanimi informacijskimi vojnami za javno mnenje oziroma uporabo strateških komunikacij je bila med Rusijo in Ukrajino med ukrajinsko krizo zaradi ruske priključitve Krima, zgodaj leta 2014. Rusija je z dobro pripravljenim konceptom strateških komunikacij vplivala na Ukrajino na vseh področjih, od diplomacije, ekonomije, kulture, vojske do medijev. Nekaj zanimivih primerov teh aktivnosti: priznanje diplom ukrajinskih vojaških šol in omogočen »časten prestop ukrajinskih vojakov v rusko vojsko«, nadzor nad množičnimi mediji, predvsem z uvedbo ruske televizije, ki je pogosto edini dostopni medij ${ }^{18}$, informacijska vojna za interpretacijo sestrelitve malezijskega potniškega letala nad Ukrajino, uporaba internetnih trolov ipd. (Analysis of Russia's Information Campaign against Ukraine, 2015).

General Stoltz ${ }^{19}$ je na podlagi svojih izkušenj, ki jih je pridobil kot poveljnik brigade na Kosovu, o zamisli »Gain hearts and minds ${ }^{20} \ll$ trdil, da je preveč ambiciozna in neizvedljiva. Kar potrebuje Nato, je, da doseže popolno sprejetost v okolju, v katerem deluje, da bi se tako čim bolj zmanjšal odpor do aktivnosti za dosego zastavljenega cilja. Zato potrebuje celosten pristop na področju informacijske kampanje, v civilno-vojaških odnosih, sodelovanju s ključnimi osebami ipd. Vse to je mogoče z uresničevanjem koncepta strateških komunikacij, ki z usklajenim pristopom izvaja vse omenjene aktivnosti in gradi celostno in verodostojno sliko Natovih aktivnosti v okolju (NATO Strategic Communications Conference, 2010).

$\mathrm{Na}$ tej točki je izčrpan pregled vsebine, značilnosti, metod in elementov obravnavanega koncepta. Zdaj bi moralo bralcu biti jasno, kaj so strateške komunikacije in čemu so namenjene ter kakšna je njihova pomembnost v okolju

\footnotetext{
18 Na pomoč Ukrajini je v televizijski vojni s separatisti januarja 2016 priskočila tudi Slovenija z donacijo televizijskega in radijskega oddajnika za informacijsko vojno oz. proti ruski propagandi (Frelih, 2016).

${ }^{19}$ Generalpodpolkovnik (lieutenant general) Philippe Stoltz, takratni poveljnik JFC Lisbona, na NATO Strategic Communications Conference v Lizboni 12.-14. aprila 2010.

${ }^{20}$ V prevodu osvojiti srca in misli.
} 
sodobnih varnostnih izzivov. Ali jih uporabljajo tudi v SV, na Ministrstvu za obrambo in v širšem okolju Republike Slovenije, pa je tema naslednjega poglavja.

\section{KONCEPT STRATEŠKIH KOMUNIKACIJ V SLOVENSKI VOJSKI IN ŠIRŠE}

V Resoluciji o nacionalni varnosti Republike Slovenije najdemo zapisano, da je v evroatlantskem prostoru verjetnost izbruha oboroženih meddržavnih spopadov močno zmanjšana, hkrati pa se je v tem prostoru povečala ranljivost držav zaradi asimetričnih groženj in tveganja, katerih nosilci so praviloma nedržavni subjekti, njihov učinek pa ima poudarjeno transnacionalno razsežnost (ReSNV-1, Uradni list, št. 27/2010). Zavedanje države, da je varnostno okolje spremenjeno, je čedalje bolj prisotno, obstaja tudi zavedanje, da le s konvencionalno silo ni več mogoče voditi boja proti vsem prihajajočim izzivom. Vendar ni opaziti prave volje, ne politične ne vojaške, za spreminjanje novih konceptov v realno delovanje.

Ugotavljanje, ali so za to krivi pomanjkanje denarja, odsotnost politične volje, pomanjkanje izobraženega kadra in želje vodilnih po usklajenem, celostnem, nekinetičnem, informacijskem pristopu k reševanju sodobnih varnostnih izzivov, ni namen tega članka, res pa je, da v Sloveniji in na MO ter v SV koncept še ni zaživel.

Država, ministrstvo in vojska so šele na začetku spoznavanja koncepta strateških komunikacij, začenjajo se šele zavedati vsebine koncepta, niso pa še spremenili miselnosti, da Natov koncept strateških komunikacij ni sinonim za odnose z javnostmi. Obstaja sicer zavedanje o nujnosti in pomembnosti usklajenega in ciljno usmerjenega pojavljanja vseh državnih elementov v mednarodnem in domačem okolju, a niti SV niti Slovenija še nista na poti uvajanja koncepta v uporabo na vseh ravneh delovanja. Trditev potrjujejo analizirani dokumenti z obravnavanega področja, intervju in pogovori s pomembnimi posamezniki, ki delujejo na tem področju, ter pregled stanja, kar bo predstavljeno v nadaljevanju. Pred analizo stanja in razmer za postavitev strateških komunikacij v slovenskem okolju je treba v teoriji poznati Natov načrt njihovega razvoja na nacionalni ravni.

\subsection{Natov načrt razvoja zmogljivosti strateških komunikacij v državah članicah}

Natov načrt razvoja koncepta strateških komunikacij poteka od leta 2010 in še ni dokončan, predvsem zaradi (ne)uvajanja koncepta $\mathrm{v}$ nacionalne vojske ter zaradi neslutenih možnosti njegovega razvoja in zmogljivosti.

Uvedba koncepta zahteva veliko dela za posamezno državo članico ali vojaško organizacijo. Nujen je celostni pristop, od izdelave smernic (v izvirniku roadmap) razvoja strateških komunikacij, ki bodo skladne s poslanstvom lastne vojske in $\mathrm{z}$ zavezništvom. Smernice in določila je treba zapisati v doktrino, vnesti v 
organizacijsko strukturo, izvajati znotraj usposabljanja in oblikovanja voditeljev ter ključnega kadra, pripraviti gradivo, zgraditi zmogljivosti in zagotoviti interoperabilnost. Nato osnovne korake uvedbe koncepta strne $\mathrm{v}$ kratico DOTMLPFI, ki v izvirniku pomeni: Doctrine, Organisation, Training, Material, Leadership, Personnel, Facilities and Interoperability. Vse to služi kot podlaga za nadaljnji razvoj koncepta (MCM-0085-2010).

To bi moral biti prvi korak na poti SV k uveljavljanju koncepta v operativno rabo.

Temeljni (pred)korak na poti uvajanja strateških komunikacij na ravni SV je bil narejen med letoma 2013 in $2014^{21}$. Nastal je na taktični ravni kot poveljniška namera zagotoviti nemoteno usposabljanje in vaje SV na pomembnem strateškem območju Osrednjega vadišča SV Postojna. Iz potrebe po omogočanju nemotenega delovanja enot na terenu so se zgodili nekateri strateški premiki v odnosu lokalnega okolja do sprejemljivosti SV na Postojnskem. V ta namen je bila na ravni 1. brigade $\mathrm{SV}$, nedoktrinarno, a iz potrebe, ustanovljena skupina za informacijske dejavnosti $(\mathrm{SID})^{22}$. Po njenih prvih uspehih so zamisel in dobre prakse skupine, ki bi morala prerasti v sistem strateških komunikacij (uveljavljan s strateške ravni MO in SV, navzdol do taktične), počasi izgubljale svoj učinek in uporabnost, saj je bila raven delovanja prenizka (taktična), manjkale so politične usmeritve in podpora. Iz intervjuja z brigadirjem Škerbincem ${ }^{23}$ je mogoče razbrati, da brigadir celotnega uspeha skupine ne pripisuje samo zmogljivostim strateških komunikacij, ampak tudi temu, da so se v brigadi resno in motivirano lotili stvari, da so se trudili slediti stroki ter da so delali kot povezana, usklajena ekipa. In sklene z mislijo: »Gre nedvomno za zadevo, ki se mora postaviti na strateškem nivoju. Morda manjka ravno tisto, kar je krasilo nas $\mathrm{v}$ brigadi (motiviranost, prepričanje, zgodba in usklajevanje).«

\footnotetext{
${ }^{21}$ Predvsem je viden učinek usklajene, načrtne in stalne uporabe zmogljivosti StratCom na primeru osrednje vaje SV Premik 2013, ko je 1. brigada SV po cesti od Pivke do osrednjega vadišča SV Postojna brez (pričakovanega) odpora lokalnega prebivalstva premaknila tanke pa tudi na primeru mednarodne vojaške vaje Takojšen odgovor 2014.

${ }^{22}$ Skupina za informacijske dejavnosti je prevzela funkcijo združevanja in povezovanja delovanja $v$ informacijskem okolju in ni bila zmogljivost sama zase. Izvajala je štabne procese združevanja in analiziranja vojaških informacij ter podporne informacijske dejavnosti. Odgovorna je bila za pripravo predvsem nevojaških, nemalipulativnih ukrepov in aktivnosti, ki obsegajo tudi sodelovanje oz. angažiranje 1. brigade v civilnem okolju, obveščanje javnosti ter komuniciranje z njimi ter CVS za informiranje in ozaveščanje javnosti o SV in njenih aktivnostih (SOP št. 1007, 2). Njena glavna naloga je bila usklajevanje in vzpostavitev dialoga na področju informacijskih dejavnosti ter vključevanje v načrtno, usmerjeno, usklajeno in vodeno sodelovanje različnih enot in funkcionalnih področij 1. brigade in SV v civilnem okolju. Usklajevanje in sodelovanje sta se izvajala skladno z operativnimi usmeritvami in ob pomanjkanju strateških usmeritev nadrejenih poveljstev (SOP št. 1007, 3).

${ }^{23}$ Brigadir Miha Škerbinc je bil poveljnik 1. brigade v letih od 2012 do 2014 (bil je vodja vaj Premik 2013 in Takojšen odgovor 2014) in je med najbolj zaslužnimi za poskus uvedbe koncepta strateških komunikacij v SV. Danes je namestnik direktorja oddelka za vojaško načrtovanje in vojaško politiko Natovega vojaškega odbora, kjer se srečuje z vsem, kar je povezano z Natovo obrambno politiko, tudi s strateškimi komunikacijami, in je zato odličen sogovornik o izbrani temi.
} 


\subsection{Presek trenutnega stanja na področju informacijskih dejavnosti na MO in v SV}

V SV (in na MO) je od vseh dejavnosti strateških komunikacij razvito le področje (vojaških) odnosov z javnostmi. Na ravni ministrstva je oblikovana Služba za strateško komuniciranje, na ravni SV Oddelek za odnose z javnostmi. Delovanje obeh je omejeno na obveščanje javnosti prek medijev ter medijsko pripravo ključnih posameznikov.

Skladno s Srednjeročnim obrambnim programom RS 2016-2020 bo strateško komuniciranje še naprej usmerjeno v promocijo obrambnega sistema in izboljšanje razumevanja vloge oboroženih sil v sodobni družbi. Oblikovane in uveljavljene bodo strategije komuniciranja z javnostmi za prednostna področja razvoja obrambnih zmogljivosti. Posebna pozornost bo $\mathrm{v}$ strategijah komuniciranja namenjena obveščanju, obveščanju in ozaveščanju javnosti o delovanju SV in drugih delov obrambnega sistema pri obrambi RS, nalogah in obveznostih, ki izhajajo iz članstva RS v mednarodnih obrambno-političnih organizacijah, ter z delovanjem znotraj sistema varstva pred naravnimi in drugimi nesrečami. Z uresničevanjem komunikacijskih načrtov in usklajenim nastopanjem vseh nosilcev obrambnega sistema bo izboljšana učinkovitost komunikacijskih aktivnosti (SOPR, 2016).

SOPR napoveduje, da bo do konca letošnjega leta proučena ustreznost vsebinske in kadrovske organiziranosti področja strateškega komuniciranja na MO. Pri razvoju strateškega komuniciranja pa bodo upoštevane dobre prakse, uveljavljene $\mathrm{v}$ mednarodnem okolju (SOPR, 2016). In prav to določilo je lahko podlaga za dobro premišljeno, integrirano in usklajeno uvedbo koncepta strateških komunikacij na raven $\mathrm{MO}$ in $\mathrm{SV}$.

Decembra 2016 je bila na seji vlade ${ }^{24}$ predstavljena Informacija o Strateškem pregledu obrambe 2016. Ugotovitve so, da na obrambnem področju primanjkuje strateškega komuniciranja in je premalo poudarka na javni diplomaciji. Interakcije $\mathrm{z}$ javnostmi (doma, v mednarodnih operacijah) je treba nadgraditi $\mathrm{z}$ uporabo vseh načinov strateškega komuniciranja na obrambni in nacionalni ravni. Služba za strateško komuniciranje je zadolžena za področje odnosov z javnostmi.

Tudi v Vojaški doktrini SV koncepta strateških komunikacij ni mogoče najti, kar je posledica dejstva, da je bila napisana leta 2006, ko tudi v zavezništvu tega koncepta še ni bilo. Je pa treba omeniti, da so v njej omenjene vse štiri zmogljivosti strateških komunikacij, ki tvorijo doktrinarno podlago za uvedbo koncepta. Drugih pravnih predpisov s tega področja ni ${ }^{25}$, opreti se je mogoče le na dejstva, navedena v SOP 1007, in delno na Direktivo za sodelovanje SV s civilnim okoljem, št.: 804-366/20151 , vendar je to le teoretično in idejno izhodišče, ne pa platforma za obdelavo.

\footnotetext{
${ }^{24}$ Na 115. redni seji Vlade RS 22. decembra 2016.

${ }^{25}$ Ključni (zastarel in edini) dokument s tega področja je le Navodilo o načinu obveščanja javnosti o delu MO RS, št. 017-04-36/99, z dne 9. 11. 1999.
} 
Izzivi v okolju delovanja so na podlagi dokumentov dokazano prepoznani in so pokazali potrebo po načrtovanem in usklajenem vstopu MO in SV v okolje, znotraj katerega deluje tudi informacijsko-komunikacijsko področje. Dejstvo podkrepi odgovor, ki ga je na vprašanje »Zdaj vidite RS od daleč, z drugega zornega kota. Mogoče imate kakšen nasvet v zvezi z uveljavljanjem koncepta StratCom v SV?« dal brigadir Škerbinc: »Osebno sem prepričan, da je čas, da resno pristopimo k zadevi. Potrebujemo jo iz treh razlogov. Prvič se je treba odzvati na sodobne izzive varnosti, spopad s hibridnimi grožnjami ni več možen brez kvalitetnega koncepta StratComa. Drugič, kakršna koli bo že rešitev izhoda iz trenutnega stanja na področju obrambe, bo to zahtevalo ne samo strokovni in politični, ampak tudi širši družbeni konsenz, v katerem ima StratCom ponovno 'glavno vlogo'. In tretjič, prav bi bilo, da se tudi na tem področju postavimo v okvire dogovorjenih standardov $\mathrm{v}$ zavezništvu.«

Trenutno v obrambnem sistemu zares delujejo samo odnosi z javnostmi MO in ločeno SV, ki delata nepovezano, kar ni več dovolj. Najlažje je trditev podkrepiti s primeri, ko bi usklajena uporaba in aktiviranje vseh zmogljivosti obrambnega sistema na obravnavanem področju prinesla boljše rezultate. Pri vprašanju pridobivanja kadra bi lahko s skupnimi in usklajenimi aktivnostmi enot SV, Sektorja za pridobivanje kadra, upravami za obrambo, obema (MO in SV) službama za odnose z javnostmi ipd. naredili več, oblikovali in »prepričljivo prodajali« skupno zgodbo o »službi domovini«. Na primeru reševanja sprejetosti SV na območju Osrednjega vadišča SV Postojna ${ }^{26}$, kjer bi s skupnim in usklajenim nastopom javne diplomacije MO, strateških usmeritev države, dobrim piarom in aktivnostmi na terenu lahko redefinirali odnose v okolju, našli skupno rešitev na ravni civilnovojaških odnosov in poslali v okolje jasno sporočilo, na primer: »Poček ostaja osrednje vadišče SV.« Podobno je s primeri sodelovanja SV v mednarodnem okolju, ker se sistem sooča z neskladji že pri iskanju soglasja ob napotitvi, pa tudi pozneje na območju delovanja z iskanjem interoperabilnosti ipd. Aktualne zavezniške strateške usmeritve o sprejetju koncepta strateških komunikacij niso integrirane $\mathrm{v}$ slovenske nacionalne dokumente. Pri pregledu dokumentov je zaznati pomanjkanje splošnih zavezniških smernic za razvoj bolj povezljivih, interoperabilnih, mobilnih in vzdržljivih zmogljivosti strateških komunikacij.

Delujemo v okolju, ki prinaša nove izzive. Neusklajen in vsebinsko neenoten pristop v takšno okolje povzroča zmedo (vsebinsko, pojmovno), neusklajen nastop

\footnotetext{
26 Sprejemljivost SV na Postojnskem in na osrednjem vadišču SV je bila od začetka gospodarske krize (od 2009) in s spreminjanjem sodobnega varnostnega okolja ter dojemanja ogroženosti vedno manjša. Med lokalno populacijo je veljalo, da tam SV in njeni zavezniki niso dobrodošli, postavljali so barikade in prometno signalizacijo, ki ni dovoljevala gibanja vojaških vozil in pripadnikov, celo na območju v lasti MO, očitali so, da prihaja do izpada turizma zaradi aktivnosti SV na vadišču, izpostavljali okoljsko in naravovarstveno problematiko, pojavili so se očitki, da SV prodaja slovensko zemljo tujcem, ko so na vadišču potekale mednarodne vojaške vaje, ipd. Razen prej omenjenih primerov dobrih praks na vajah enot SV in projekta »obnove objekta na Bilah« še danes obrambni resor nima enotnega stališča do vprašanj, povezanih z vadiščem SV v Postojni, kar lokalno prebivalstvo in voditelji s pridom izkoriščajo.
} 
in druge težave pri delovanju SV v civilnem okolju in na območju delovanja, od taktične do strateške ravni.

Zato je čas, da se v strateške dokumente zapiše potreba po nujni in takojšnji uvedbi koncepta strateških komunikacij v odločanje in načrtovanje, saj si MO in SV tudi tako povečujeta verodostojnost in izboljšujeta uspešnost delovanja.

\subsection{Kako na pot do uvedbe koncepta strateških komunikacij v SV}

Zaznanih je še veliko situacij, v katerih bi SV in MO potrebovala koncept strateških komunikacij za uspešnejše delovanje in povečanje sprejetosti v okolju. Takšne so predlog o ukinitvi vojske, negativna ocena njene bojne pripravljenosti, pozivanje načelnika Generalštaba k odstopu, zmanjšanje zaupanja v SV na podlagi javnomnenjskih raziskav, sprejetost delovanja pripadnic in pripadnikov SV v mednarodnih operacijah in na misijah ipd.

Za začetek morata SV in MO spodbuditi dovolj veliko zanimanje za uvajanje koncepta in pripravljenost za spremembe. Sprejeti odgovornost in postaviti jasne cilje in vizijo. Odgovoriti je treba na kritična vprašanja, povezana z uvajanjem novih konceptov, da bi si ustvarili primeren StratCom mindset ${ }^{27}$, ki bo omogočil opredelitev nacionalnih ciljev znotraj tega koncepta ter razvoj in usklajenost delovanja z zaveznicami:

- kakšna je dodana vrednost strateških komunikacij za RS, MO in SV;

- ali se zavedamo pomena strateških komunikacij na vseh ravneh delovanja;

- kdo je strokovnjak, svetovalec za strateške komunikacije;

- imamo dovolj znanja in kadrov za vzpostavitev novega koncepta;

- kako bo koncept strateških komunikacij spremenil že delujoče procese in vplival nanje;

- ali imamo dovolj natančno določen koncept informacijskega in psihološkega delovanja ter javne diplomacije;

- kaj narediti v operacijah, v katerih bo zahtevan pristop strateških komunikacij;

- kakšna je prihodnost SV v operacijah strateških komunikacij;

- ali poznamo 'zgodbo SV', ali vemo kaj so ključna sporočila;

- kaj smo že in kaj bomo kot država/SV naredili za izboljšanje (Nato);

- ali se poveljniški kader (na najvišjih in hkrati najnižjih ravneh vodenja in poveljevanja) zaveda pomena strateških komunikacij;

- kakšni so naši odnosi z zavezništvom na področju strateških komunikacij.

Odgovori na ta vprašanja in še na katerega (npr. finančne omejitve ipd.) nas postavijo na zemljevid strateških komunikacij: da lahko najdemo začetek, pa ne smemo spregledati tega, da je »dirigent« Vlada RS in bi prav ona morala $\mathrm{s}$ strateškimi smernicami podpreti razvoj strateških komunikacij v SV.

27 V prevodu: StratCom-zavedanje. 
Sklep Nato se srečuje z novo strateško realnostjo. Splošno rečeno je cilj strateških komunikacij vzpostaviti vojaško-politično komuniciranje bolj strateško in sposobno vplivanja na obnašanje in mišljenje izbrane ciljne populacije.

Pomen, ki ga zavezništvo pripisuje strateškim komunikacijam, lahko razberemo na podlagi zapisane teorije, izdanih usmeritev in načel izvajanja strateških komunikacij ter iz zapisanih primerov. S primerno in načrtovano uporabo strateških komunikacij lahko dosežemo, da zaznave postanejo resničnost. In to je ključni moment delovanja zavezništva $\mathrm{v}$ nekem okolju, ob hkratnem poteku kinetičnih in drugih nekinetičnih aktivnosti. Koncept strateških komunikacij se je izkazal za enega izmed bolj vitalnih delov delovanja zavezništva in še pridobiva pomen. V sodobnih vojnah, kot so vojne v Iraku, Afganistanu in Siriji, ima vplivanje vedno večjo vlogo. Prav tako je jasno, da strateške komunikacije kot koncept sodobnega nekinetičnega delovanja in bojevanja proti novim ter nastajajočim nepredvidljivim grožnjam sodobnega sveta še niso dosegle vrha svojega razvoja in uporabe $\mathrm{v}$ vojaških operacijah.

Strateške komunikacije so »srce« Natovih prizadevanj za doseganje podpore in sprejemljivosti interesov zavezništva na izbrani ciljni populaciji, a niso in ne morejo biti proces, ki poteka sam zase. Vključen mora biti v celoten postopek operativnega načrtovanja in izvajanja operacij, vojska pa mora zagotavljati podporo njegovemu delovanju.

Pregled strateških dokumentov (pregled obrambe, zunanje strategije RS, srednjeročni obrambni program ipd.) privede do ugotovitve, da v RS, na MO in v SV pomen strateških komunikacij še ni v celoti prepoznan, doktrinarno opredeljen in uporabljen. Na podlagi intervjuja in pregleda sedanjega stanja je razvidno, da se na ravni posameznikov pojavljata poznavanje koncepta strateških komunikacij in zavedanje o njegovi pomembnosti, na organizacijski ravni pa koncept še ni urejen niti celostno uveden, temveč le njegovi posamezni elementi. Na obravnavanih ravneh so to odnosi z javnostmi in ponekod javna diplomacija, kar pa ne omogoča uresničevanja namena in poslanstva koncepta.

Država oziroma njen nacionalnovarnostni sistem ta koncept nujno potrebuje. To izhaja iz obljub zavezništvu po uvedbi enotnih standardov, iz nujnosti prožnega odzivanja na sodobne izzive varnosti in iz namena po iskanju širšega družbenega ter strokovnega konsenza o zgodbi in prihodnjem razvoju RS znotraj in zunaj nacionalnih meja. Koncept je treba doktrinarno sprejeti in uvesti v uporabo od vladne ravni do resornih ministrstev ter njihovih organov v sestavi (v obravnavanem primeru integrirano na MO in v SV). Z uvedbo koncepta strateških komunikacij bo RS ostala verodostojen partner doma in v zavezništvu, dosežen bo celostni pristop $\mathrm{k}$ oblikovanju ciljev organizacije in reševanju njenih izzivov. Tako bo Slovenija pripravljena na morebitno krizno posredovanje tudi na informacijskokomunikacijskem področju. In ne gre pozabiti niti na misel, s katero je brigadir Škerbinc končal svoj intervju: ne gre namreč samo za to, da bi bilo pravilno 
komuniciranje v interesu MO in SV, temveč tudi za pravico državljanov, da so kakovostno obveščeni o zadevah, povezanih z varnostjo in obrambo. Na globalnem varnostnem področju se dogajajo tektonske spremembe, jaz pa nimam občutka, da jih v Sloveniji v povprečju sploh razumemo.

Primarni interesi in cilj RS na obrambnem področju bi z uvedbo koncepta strateških komunikacij morali biti prednostno usmerjeni k oživitvi ugleda SV v družbi in k zagotovitvi pravilne zaznave družbe o potrebi po oboroženih silah ter vlogi in nalogah RS kot polnopravne članice zavezništva v mednarodnem okolju.

Če želimo razumeti celovitost in vse prednosti uvedbe in učinkovite uporabe strateških komunikacij v SV in na MO, bo treba poiskati najprej jasne strateške usmeritve države na obrambno-varnostnem področju. Treba bo spremeniti miselnost poveljnikov, načrtovalcev in vzpostaviti »StratCom mindset« po vzoru Natovega.

\section{Literatura in viri}

1. ACO Strategic Communications, ACO AD 95-2.

2. Allied Command Operations Comprehensive Operations Planning Directive (ACO COPD), 2010. Supreme Headquarters Allied Power Europe Belgium.

3. Allied Joint Doctrine For Information Operations (AJP-3.10), 2009.

4. Annalysis of Russia's Information Campaign against Ukraine, 2015. Nato StratCom COE, Riga, Latvia.

5. Bučar, B., 2000. Navodila za pisanje: seminarske naloge in diplomska dela. Knjižna zbirka Profesija, FDV, Ljubljana.

6. DoD Strategic Communication: Integrating Foreign Audience Perceptions into Policy Making, Plans, and Operations, (GAO-12-612R) 2012: http://www.gao.gov/products/ GAO-12-612R (10. 6. 2016).

7. Frelih, P., 2016. Na pomoč Ukrajini v televizijski vojni s separatisti. Delo, 29. 1. 2016.

8. Furlan B. [in drugi] (2006): Vojaška doktrina. Ljubljana, Defensor.

9. Heddock, E. K., 2002. Winning with words: Strategic Communications and the War on Terrorism. National Defense University, National War College, Washington.

10. Informacija o sklepih Strateškega pregleda obrambe 2016.

11. Javna diplomacija: http://brussels.mission.si/index.php?id=3020 (16. 12. 2016).

12. Mapping of StratCom - Practices in the Nato Countries, 2015. Nato Strategic Communication Centre of Excellence, Riga: http://www.stratcomcoe.org/mappingstratcom-practices-nato-countries-0 (12.12. 2016).

13. MC 422/3 Nato Military Policy on Information Operations, 2009. Nato.

14. Melissen, Jan. 2005. The New Public Diplomacy: Between Theory and Practice. V The New Public Diplomacy. Soft Power in international Relations, ur. Melissen, Jan, 3-27. London: Palgrave Macmillan.

15. Military Concept for Nato Strategic Communications, MCM-0085-2010, May 2012.

16. NATO Strategic Communications Conference, 2010. Strategic Communications: from Theory to Practice - Post-Conference Report, April 12-14 2010, Lisbon, Portugal.

17. Nato Strategic Communications Policy, DSG(2010)0528, September 2009.

18. Reeding A., Weed K., Ghez J., 2010. Nato's Strategic Communications concept and its relevance for France. Rand cooperation, 2010: http://www.rand.org/content/dam/rand/ pubs/technical_reports/2010/RAND_TR855.2.pdf(15. 12. 2016). 
19. Resolucija o strategiji nacionalne varnosti Republike Slovenije (ReSNV-1). Uradni list RS, št. $27 / 2010$.

20. Skelton I. (ed), 2008. Security and Stability in Afghanistan and Iraq: Developments in U.S. Strategy and Operations and the Way Ahead, Hearing before the Committee. U.S. House of Representatives, Diane Publishing Co, USA.

21. Slovenija: varna, uspešna in v svetu spoštovana. Zunanja politika Republike Slovenije. RS, Ministrstvo za zunanje zadeve, Ljubljana, 2015.

22. SOP št. 1007 Poveljstvo 1. brigade: SOP za informacijske dejavnosti v 1. brigadi SV, 2016.

23. Strategic Communications analyze: www.google.com/analytics/ (10. 6. 2016).

24. Škerbinc, M, 2017. Nestrukturiran dopisni intervju-uvajanje koncepta StratCom v SV. Ljubljana, Bruselj, 7. 1. 2017.

25. Tatham, M.P., 2008. Strategic Communication: A Primer. Advanced Research and Assessment Group, Special Series 08/28, Defence Academy of the United Kingdom, GB.

26. Tuch, Hans, 1990. Communicating with the world. New York. St. Martin's Press.

27. What is Nato: http://www.nato.int/nato-welcome/index.html (5. 1. 2017). 